OPEN ACCESS

Edited by: Thomas Efferth, Johannes Gutenberg-Universität Mainz, Germany

Reviewed by:

Muriel Cuendet

Université de Genève, Switzerland

Wei Wang,

Hunan University of Chinese Medicine, China

${ }^{*}$ Correspondence:

Maciej Strzemski

maciej.strzemski@poczta.onet.pl

Artur Wnorowski

artur.wnorowski@umlub.p

Magdalena Wójciak-Kosior kosiorma@wp.pl

Specialty section: This article was submitted to

Ethnopharmacology,

a section of the journal

Frontiers in Pharmacology

Received: 06 April 2017

Accepted: 29 May 2017

Published: 13 June 2017

Citation:

Strzemski M, Wojnicki K, Sowa I, Wojas-Krawczyk K, Krawczyk $P$,

Kocjan R, Such J, Latalski M, Wnorowski A and Wójciak-Kosior M (2017) In Vitro Antiproliferative Activity of Extracts of Carlina acaulis subsp. caulescens and Carlina acanthifolia subsp. utzka.

Front. Pharmacol. 8:371. doi: 10.3389/fphar.2017.00371

\section{In Vitro Antiproliferative Activity of Extracts of Carlina acaulis subsp. caulescens and Carlina acanthifolia subsp. utzka}

\author{
Maciej Strzemski ${ }^{1 *}$, Kamil Wojnicki2,3, Ireneusz Sowa', Kamila Wojas-Krawczyk ${ }^{4}$, \\ Pawel Krawczyk ${ }^{4}$, Ryszard Kocjan', Justyna Such ${ }^{5}$, Michał Latalski6, Artur Wnorowski ${ }^{5 *}$ \\ and Magdalena Wójciak-Kosior ${ }^{1 *}$
}

'Department of Analytical Chemistry, Medical University of Lublin, Lublin, Poland, ${ }^{2}$ Laboratory of Molecular Neurobiology, Nencki Institute of Experimental Biology Polish Academy of Sciences, Warszawa, Poland, ${ }^{3}$ Department of Synthesis and Chemical Technology of Pharmaceutical Substances, Medical University of Lublin, Lublin, Poland, ${ }^{4}$ Department of Pneumology, Oncology and Allergology, Medical University of Lublin, Lublin, Poland, ${ }^{5}$ Department of Biopharmacy, Medical University of Lublin, Lublin, Poland, ${ }^{6}$ Children's Orthopedics Department, Medical University of Lublin, Lublin, Poland

Various species of the Carlina genus have been used in traditional medicine in many countries to treat numerous skin disorders, including cancer. The objective of this work was to assess the anticancer properties of root and leaf extracts from Carlina acaulis subsp. caulescens and C. acanthifolia subsp. utzka. Anti-tumor properties of the extracts were explored using a tetrazolium-based cell viability assay and flow cytometric apoptosis analysis, followed by immunodetection of phosphoactive ERK1/2 in UACC903, C32, and UACC-647 human melanoma cell lines. Normal human fibroblasts were used as a control. Leaf extracts inhibited the viability of all tested melanoma cell lines in a dose-dependent fashion while the fibroblasts were less sensitive to such extract. The root extracts inhibited the proliferation of UACC-903 and UACC-647 cells only at the highest doses $(300 \mu \mathrm{g} / \mathrm{mL})$. However, the $\mathrm{C} 32$ and fibroblast cells exhibited an increase in the cellular proliferation rate and no caspase activity was observed in response to the root extracts $(100 \mu \mathrm{g} / \mathrm{mL})$. An increase in caspase activity was observed in melanoma cells treated with the leaf extracts of both Carlina species. Leaf extracts from $C$. acaulis subsp. caulescens $(100 \mu \mathrm{g} / \mathrm{mL})$ inhibited proliferatory ERK1/2 in UACC-903 and C32 cells, as demonstrated by the decrease in ERK1/2 phosphorylation. No reduction in phospho-ERK1/2 was observed in the tested cell lines treated with the root extracts, apart from UACC-647 after incubation with the $C$. acanthifolia subsp. utzka root extract (100 $\mu \mathrm{g} / \mathrm{mL}$ ). There was no change in ERK1/2 phosphorylation in the fibroblasts. The extracts from the leaves and roots were analyzed by HPLC and the analysis showed the presence of triterpenes and phenolic acids as the main extract components. The research demonstrated that the extracts from the leaves of the plants were cytotoxic against the human melanoma line and induced apoptosis of the cells. The triterpene fraction present in the tested extracts may be responsible for this activity.

Keywords: Carlina sp., triterpenes, chlorogenic acid, melanoma, cytotoxicity, apoptosis, ERK1/2 phosphorylation 


\section{INTRODUCTION}

The genus Carlina (Asteraceae) comprises over 30 species found in their natural habitat in Europe and Asia (Tutin et al., 1976). Various species of Carlina genus, e.g., C. acaulis, C. acanthifolia, C. utzka (C. acanthifolia subsp. utzka) and C. corymbosa are still used in traditional medicine in Spain (Bonet et al., 1999), Italy (Menale et al., 2006; Guarino et al., 2008), Hungary (Dénes et al., 2012), Poland (Strzemski et al., 2014b), Lithuania (Henneberg, 2002), and the Balkan countries (Jarić et al., 2007; Redžić, 2007; Šarić-Kundalić et al., 2010; Menković et al., 2011; Pieroni et al., 2014) mostly for their cholagogic, diuretic, antibiotic, and cleansing effects (Guarrera, 2003). The herb extracts are applied externally to facilitate healing of skin lesions (Jarić et al., 2007; Menković et al., 2011; Rexhepi et al., 2013). Practitioners of traditional medicine also employ C. acaulis as an anti-cancer drug (Duke et al., 2002; Henneberg, 2002; Miler, 2009); however, no experimental data on anti-tumorigenic activity of Carlina are not available.

The number of data on the chemical composition of Carlina plants is limited. It has been reported that the root of C. acaulis contains inulin (Đordević et al., 2005, 2007, 2012; Stojanović-Radić et al., 2012), essential oil (Đordević et al., 2012), and trace amount of lupeol (Strzemski et al., 2016). In the herb, such flavonoids as orientin, homoorientin, isoschaftoside, vitexin, apigenin 7-O-glucoside, and apigenin (Raynaud and Rasolojaona, 1979; Đordević et al., 2012) as well as chlorogenic acids (Jaiswal et al., 2011) and pentacyclic triterpenes: lupeol, lupeol acetate, $\alpha$-amyrin, $\beta$-amyrin, $\beta$-amyrin acetate, betulinic acid, oleanolic acid, and ursolic acid (Strzemski et al., 2016) have been identified.

Carlina acanthifolia subsp. utzka is rare and registered as an endangered species. It can only be found in a few sites in Poland and Ukraine (Strzemski et al., 2014a). It has been reported that the root of C. acanthifolia subsp. utzka contains trace amount of pentacyclic triterpenes. Its leaves have been identified to contain betulinic, oleanolic, and ursolic acids (Strzemski et al., 2016).

The aim of the research was to verify whether there are any premises justifying the traditional use of Carlina plants in folk methods for skin cancer treatment. In order to verify the antitumor activity of the plats from Carlina species, we prepared extracts from the leaves and roots of $C$. acaulis subsp. caulescens and C. acanthifolia subsp. utzka and evaluated their capacity to induce cytotoxicity and apoptosis and modulate ERK1/2 phosphorylation in UACC-903, C32, and UACC-647 human-derived melanoma cell lines and in $\mathrm{BJ}$ normal human foreskin fibroblasts. We examined the chemical composition of the extracts in order to identify compounds responsible for the antiproliferatory activity.

Skin cancer is one of the most common types of cancer and is mostly caused by extensive exposure to UV light, ionizing radiation, or chemical carcinogens. Melanoma accounts for less than $5 \%$ of all skin cancer cases. However, epidemiological reports indicate that it causes more than $75 \%$ skin cancerrelated deaths. Topical surgery and radiation therapy supported by chemo- and immunotherapy are frequently applied as a treatment. New targeted therapeutics are also being developed, including BRAF and MEK inhibitors; however, melanoma cells tend to develop drug resistance over time (Orthaber et al., 2017). Therefore, the search of compounds that can be used in the therapy is still required.

\section{MATERIALS AND METHODS}

\section{Plant Material}

The C. acanthifolia subsp. utzka (Hacq) Meusel \& Kästner and C. acaulis subsp. caulescens (Lam.) Schübl. \& G. Martens plants were obtained from the Botanical Garden of Maria CurieSkłodowska University in Lublin (latitude $51^{\circ} 16^{\prime} \mathrm{N}$, longitude $22^{\circ} 30^{\prime}$ E, altitude: $178-217 \mathrm{~m}$ a.s.l.), identified, and deposited in Botanical Garden of UMCS (C. acanthifolia subsp. utzka voucher specimen no. 2682-1979; C. acaulis subsp. caulescens voucher specimen no. 684). Taxa were identified on the basis of the monograph "Lebensgeschichte der Gold - und Silberdisteln" (Meusel and Kästner, 1994) and "Polish Plants" (Szafer et al., 1976). The plants were collected in the second half of July 2015. The roots were thoroughly washed with tap and distilled water and dried at room temperature. The photographs of the plants, together with their English and local names, are presented in Table 1.

\section{Reference Standards, Chemicals, and Apparatus}

Ursolic acid, oleanolic acid, betulinic acid, lupeol, lupeol acetate, $\beta$-amyrin, $\beta$-amyrin acetate, chlorogenic acid, and protocatechuic acid were purchased from Sigma-Aldrich (St. Louis, MO, United States). Methanol, ethanol, and dimethyl sulfoxide (DMSO) were at least for analysis grade from Polish Reagents (POCH, Gliwice, Poland). HPLC-grade acetonitrile, trifluoroacetic acid, and phosphoric acid were purchased from Merck (Merck, Darmstadt, Germany). Water for HPLC was purified by ultrapure Milipore Direct-Q ${ }^{\circledR} 3 \mathrm{UV}-\mathrm{R}$ (Merck). The analysis was performed on VWR Hitachi Chromaster 600 chromatograph with a PDA detector and EZChrom Elite software (Merck). Mass spectrometry was conducted with the use of mass spectrometer micrOTOF-Q II and data was handled by Compass DataAnalysis software version 4.1 (Bruker Daltonics, Bremen, Germany).

\section{Preparation of Samples}

The plant material was divided into roots and leaves. The samples were dried and pulverized. Each sample $(1 \mathrm{~g})$ was extracted four times with methanol $(3 \times 25 \mathrm{~mL})$ with the use of an ultrasonic bath $(4 \times 15 \mathrm{~min})$. The extracts obtained were combined, centrifuged and filtered through $0.25 \mu \mathrm{m}$ membrane filter (Millipore, Billerica, MA, United States). The extract obtained was evaporated to dryness, weighed, and dissolved in a mixture of ethanol:dimethyl sulfoxide (1.1:0.4 v/v) (final concentration was equal to $36.57 \mathrm{mg} \cdot \mathrm{mL}^{-1}$ ). Finally, the concentrated extract (CE) was analyzed by HPLC and used for biological evaluation with melanoma and fibroblast cell lines. Maximal concentration of ethanol and DMSO added to cell cultures was 0.6 and $0.2 \%$, respectively, and it has no impact on cells' morphology and cell viability. 
TABLE 1 | Plant material used in the study, including the official, British, and local names.

Carlina acanthifolia subsp. utzka (Hacq) Meusel \& Kästner*

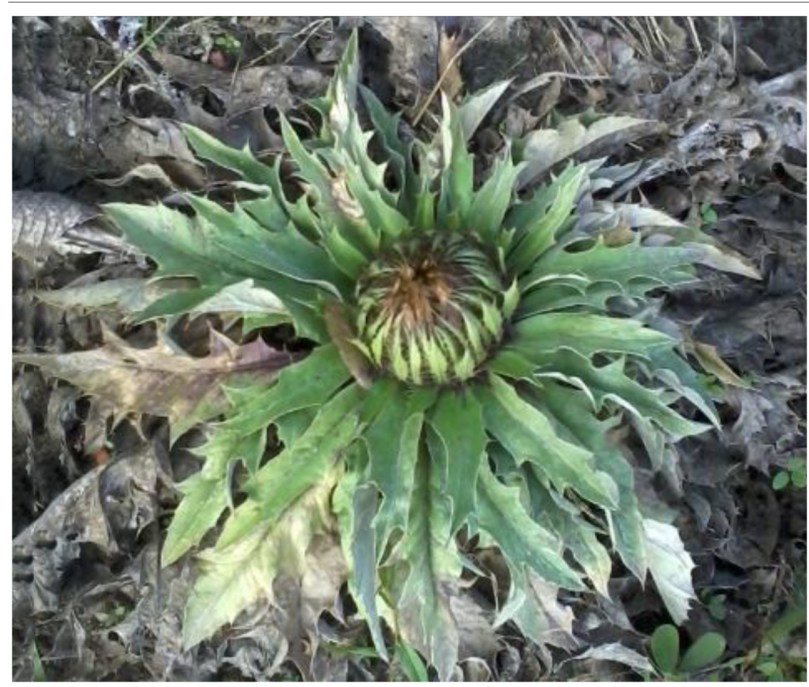

British names

No English name

Polish

Dziewięćsił popłocholistny;

Ukrainian:

Відкасник татарниколистий;

Local names
C. acaulis subsp. caulescens (Lam.) Schübl. \& G. Martens*

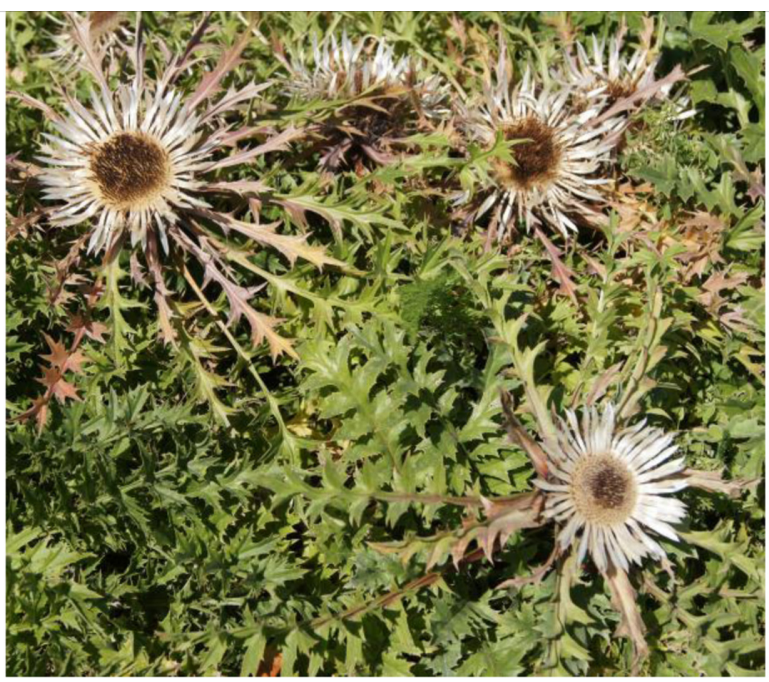

Stemless carline thistle, Dwarf carline thistle, Silver thistle.

Polish

Dziewięćsił bezłodygowy, Kołtunowe ziele,

Kâsina, Zajêcza rzepa, Karolinek,

Dziewięciornik, Czartopłoch, Osetek;

Ukrainian:

Відка́сник безстебловий;

Serbian:

Kompava, Kravljak, Rešetka, Kraljevac,

Belotrn, Pupavac.

*The official name from http://www. theplantlist.org/.

\section{Chemical Composition of Extracts Analysis of Triterpenes}

Two chromatographic systems were used as follows: RP18e LiChrospher 100 column $(25 \mathrm{~cm} \times 4.0 \mathrm{~mm}$ i.d., $5 \mu \mathrm{m}$ particle size, Merck, Darmstadt, Germany), a mixture of acetonitrile/water/1\% phosphoric acid $(75: 25: 0.5 \mathrm{v} / \mathrm{v} / \mathrm{v})$ at flow rate of $1.0 \mathrm{~mL} \cdot \mathrm{min}^{-1}$ as a mobile phase, and a temperature of $10^{\circ} \mathrm{C}$ for triterpenic acids analysis and an RP18e Chromolith 100 column $(10 \mathrm{~cm} \times 2.0 \mathrm{~mm}$ i.d., Merck), mixture of acetonitrilewater $(95: 5 \mathrm{v} / \mathrm{v})$ at a flow rate $2 \mathrm{~mL} \cdot \mathrm{min}^{-1}$ as a mobile phase, and a temperature of $25^{\circ} \mathrm{C}$ for lupeol, lupeol acetate, $\beta$-amyrin, and $\beta$-amyrin acetate. The data were collected in the wavelength range from 200 to $400 \mathrm{~nm}$. Quantitative analysis was performed at $\lambda=200 \mathrm{~nm}$.

\section{Analysis of Phenolic Compounds}

A chromatographic system consisting of an RP18e LiChrospher 100 column $(25 \mathrm{~cm} \times 4.0 \mathrm{~mm}$ i.d., $5 \mu \mathrm{m}$ particle size, Merck, Darmstadt, Germany), a mixture of acetonitrile/ water/trifluoroacetic acid (10:90:0.025 v/v/v) at a flow rate $1.0 \mathrm{~mL} \cdot \mathrm{min}^{-1}$ as a mobile phase, and a temperature of $25^{\circ} \mathrm{C}$ was used for the analysis of phenolic compounds. The data were collected in the wavelength range from 200 to $400 \mathrm{~nm}$. Quantitative analysis of chlorogenic acid and protocatechuic acid were performed at $\lambda=326 \mathrm{~nm}$ and $\lambda=260 \mathrm{~nm}$, respectively.

\section{DirectProbe APCI-MS Analysis}

The identity of the compounds was established by comparison of retention times and spectra with the corresponding standards. Chromatographic fractions eluted at retention times characteristic for the investigated triterpenes were collected using a Foxy R1 fraction collector (Teledyne Isco, Lincoln, NE, United States) and further analyzed by MS.

MS analysis was conducted according to previously published methodology (Strzemski et al., 2016).

\section{Biological Activity of Extracts Cell Culture}

UACC-647 (RRID:CVCL_4049) (Bittner et al., 2000), UACC-903 (RRID:CVCL_4052) (Trent et al., 1990), and C32 (RRID:CVCL_1097) (Barnwell et al., 1985) human melanoma cell lines were maintained in RPMI-1640 medium (Corning, 
Tewksbury, MA, United States). UACC-647 and UACC-903 were a generous gift from Michel Bernier (National Institute on Aging, National Institutes of Health, Baltimore, MD, United States). The C32 cell line was obtained from the American Type Culture Collection (ATCC, Manassas, VA, United States; CRL-1585). Human BJ fibroblasts (RRID:CVCL_3653) (Morales et al., 1999) were obtained also from ATCC (CRL-2522). The fibroblasts were cultured in Eagle's Minimum Essential Medium. All media were supplemented with $10 \%$ fetal bovine serum (FBS), $100 \mathrm{U} / \mathrm{ml}$ penicillin, and $0.1 \mathrm{mg} / \mathrm{ml}$ streptomycin, all from Sigma-Aldrich (St. Louis, MO, United States). The cell lines were cultured in a humidified atmosphere with $5 \% \mathrm{CO}_{2}$ at $37^{\circ} \mathrm{C}$. Upon receipt of the cell lines, the cells were expanded for a few passages to enable generation of new frozen stocks. The cells were resuscitated as needed and used for less than 6 months after resuscitation. ATCC performs thorough cell line authentication utilizing Short Tandem Repeat profiling.

\section{Cell Viability}

The cells were seeded out in complete medium (10\% FBS) in 96 -well plates at the densitiy of $6 \times 10^{3}$ (C32), $5 \times 10^{3}$ (UACC647, UACC-903), and $4 \times 10^{3}$ cells per well (BJ fibroblasts). After $24 \mathrm{~h}$ of culture, the supernatant was aspirated and the extracts diluted in serum free medium were added in quadruplicates. The cells were incubated for another $24 \mathrm{~h}$, and $10 \mu \mathrm{L}$ of a $0.5 \mathrm{mg} / \mathrm{mL}$ MTT (3-(4,5-Dimethyl-2-thiazolyl)-2,5-diphenyl$2 \mathrm{H}$-tetrazolium bromide) solution was added to each well, followed by incubation for $3 \mathrm{~h}$ at $37^{\circ} \mathrm{C}$. The supernatants were removed and DMSO (100 $\mu \mathrm{L}$ per well) was added to dissolve precipitated formazan. The plate was agitated for $5 \mathrm{~min}$ and absorbance was measured at 562 and $620 \mathrm{~nm}$ using an ELx800 plate reader (BioTek Instruments, Winooski, VT, United States). All the experiments were performed three times.

\section{Cell Apoptosis}

The cells were seeded in complete medium (10\% FBS) in a 6-well plate at the density of $1.75 \times 10^{5}$ (for C32 line), $1.25 \times 10^{5}$ (for UACC-647 and UACC-903 lines), and $1 \times 10^{5}$ cells per well (for BJ fibroblasts line). After $24 \mathrm{~h}$, the supernatant was aspirated and the leaf and root extracts of the examined plants were added at the concentration of $100 \mu \mathrm{g} / \mathrm{mL}$. Vehicle (EtOH:DMSO, 1.1:0.4, v:v) was used as a control. The cultures were incubated for another $24 \mathrm{~h}$ and then the cells were stained with Intracellular Caspase Detection ApoStat (R\&D System, United States) directly during the last $30 \mathrm{~min}$ of culture. Ten microliter of ApoStat per $1 \mathrm{~mL}$ of the culture volume was added, incubated at $37^{\circ} \mathrm{C}$, and after the staining period the cells were harvested, centrifuged at $500 \times g$ for $5 \mathrm{~min}$, and washed once with $4 \mathrm{ml}$ of phosphate-buffered saline (PBS) to remove unbound reagent. The cells were resuspended in $500 \mu \mathrm{L}$ of PBS and immediately analyzed by flow cytometry.

\section{Western Blotting}

The UACC-903, C32, UACC-647, and BJ cells were plated in 6 -well plates and cultured for $24 \mathrm{~h}$. Then, the cells were serumstarved for $3 \mathrm{~h}$ followed by their treatment with the leaf and root extracts from C. acaulis subsp. caulescens and C. acanthifolia subsp. utzka $(100 \mu \mathrm{g} / \mathrm{mL})$ or the vehicle (EtOH:DMSO, 1.1:0.4, $\mathrm{v}: \mathrm{v})$. Half an hour after the treatment, the cells were lysed using $1 \times$ Cell Lysis Buffer (Cell Signaling Technology) supplemented with Halt Protease Inhibitor Cocktail $(10 \mu \mathrm{L} / \mathrm{mL}$, Thermo Fisher Scientific) and Protease Inhibitor Cocktail $(10 \mu \mathrm{L} / \mathrm{mL}$, SigmaAldrich). The phosphorylation status of ERK1/2 in the cellular lysates obtained was determined using immunoblotting approach as described before (Paul et al., 2014). In brief, equal amounts of protein were separated on $4-12 \%$ precast gels (Thermo Fisher Scientific) by the means of SDS-PAGE and electrophoretically transferred onto PVDF membranes (Thermo Fisher Scientific). The membranes were then blocked using 3\% milk in $1 \times$ TBST for $30 \mathrm{~min}$. Subsequently, the membranes were incubated overnight at $4^{\circ} \mathrm{C}$ with primary antibodies raised against the phospho-ERK1/2 (\#4376) or total ERK1/2 (\#4695), both from Cell Signaling Technology. Upon 4 rounds of washing with TBST $(2 \mathrm{~min} \times 4 \mathrm{~min}$ and $2 \mathrm{~min} \times 2 \mathrm{~min})$, the membranes were incubated with HRP-linked secondary anti-rabbit antibody for 45 min. The washing was repeated and followed by detection of immunoreactive bands using the SignalFire Plus ECL Reagent (Cell Signaling Technology). The band intensities were quantified by means of volume densitometry using a Fiji image processing package (Schindelin et al., 2012).

\section{Statistical Analysis}

Statistical analyses were performed using GraphPad Prism v6.01 (GraphPad Software, Inc., San Diego, CA, United States). The data were plotted as mean \pm standard deviation (SD). Differences between the means of the treatments were evaluated using one-way analysis of variance (one-way ANOVA) followed by Dunnett's multiple comparison test. The $\mathrm{IC}_{50}$ values (halfmaximal inhibitory concentrations) were calculated by fitting the experimental values to sigmoidal equation. The selectivity index was calculated by dividing the average viability of BJ cell line by the viability of the melanoma cell line of interest in respective extracts. Significance was designated as ${ }^{*} P<0.05$, ${ }^{* *} P<0.01$, and ${ }^{* * *} P<0.001$.

\section{RESULTS}

\section{Chemical Composition of Carlina Extracts}

The HPLC analysis of C. acaulis subsp. caulescens and C. acanthifolia subsp. utzka revealed the presence of pentacyclic triterpenes and phenolic acids as the main constituents of the extracts. It needs to be pointed out that the highest amount of triterpenes was determined in the extracts from leaves and ursolic and oleanolic acids were dominant compounds within the entire set of the investigated triterpenes. The extract from the leaves of $C$. acaulis subsp. caulescens contained an approx. two-fold higher amount of ursolic acid than the extract from the leaves of C. acanthifolia subsp. utzka. Only a slight concentration of triterpenes in the form of acetates was found in the extract from the root of both species.

A significant amount of chlorogenic acid was present in all the tested extracts. In turn, protocatechuic acid was found in the extracts from the leaves but was not detected in the extracts 
from the roots. The HPLC and MS analysis results are presented in Table 2. Chromatograms and MS spectra are given in the Supplementary Material (Supplementary Figures S1-S4).

\section{Differential Regulation of Cellular Viability by Leaf and Root Extracts}

Cell viability was determined by means of MTT assay. The extracts from leaves of $C$. acaulis subsp. caulescens and $C$. acanthifolia subsp. utzka elicited dose-depended inhibition of the cellular viability of all the tested melanoma cell lines (Figures 1, 2, light bars). The UACC-903 line was the most sensitive to the C. acaulis subsp. caulescens and C. acanthifolia subsp. utzka leaf extracts with $\mathrm{IC}_{50}$ values of 43.2 and $40.1 \mu \mathrm{g} / \mathrm{mL}$, respectively. The C32 and UACC-647 cells lines exhibited moderate susceptibility to the $C$. acaulis subsp. caulescens leaf extracts $\left(\mathrm{IC}_{50}=76.7 \mu \mathrm{g} / \mathrm{mL}\right.$ and $57.9 \mu \mathrm{g} / \mathrm{mL}$, respectively) and to the C. acanthifolia subsp. utzka leaf extracts $\left(\mathrm{IC}_{50}=86.7 \mu \mathrm{g} / \mathrm{mL}\right.$ and $56.1 \mu \mathrm{g} / \mathrm{mL}$, respectively). The viability of BJ fibroblasts was also affected by the treatment with the leaf extracts, however to a lesser extent $\left(\mathrm{IC}_{50}=89.5 \mu \mathrm{g} / \mathrm{mL}\right.$ for the $C$. acaulis subsp. caulescens leaf extract and $99.6 \mu \mathrm{g} / \mathrm{mL}$ for the C. acanthifolia subsp. utzka leaf extract; Table 3).

The root extracts of $C$. acaulis subsp. caulescens and C. acanthifolia subsp. utzka elicited opposite effects on the proliferation of the cell lines of interest compared to the leaf extracts (Figures 1, 2, dark bars). Up to the dose of $150 \mu \mathrm{g} / \mathrm{mL}$, the root extracts either had no influence on cell viability whatsoever or even caused increased proliferation of the cells. This effect was clearly visible in the C32 melanoma cells, where a 24 and $40 \%$ boost in cell viability was observed in response to $150 \mu \mathrm{g} / \mathrm{mL}$ of the root extracts from C. acaulis subsp. caulescens and C. acanthifolia subsp. utzka, respectively (Figures 1B, 2B). Similarly, the growth of BJ fibroblasts increased significantly by 16 and $21 \%$ upon the same treatment (Figures 1D, 2D). Only the highest dose $(300 \mu \mathrm{g} / \mathrm{mL})$ of the C. acanthifolia subsp. utzka root extract exerted a significant inhibitory effect towards all tested cell lines (Figures 2A-D).

In order to determine the most selective dose of the extracts, the selectivity index was calculated (Figure 3). The values indicate how specific the dose in question towards the melanoma cells vs. the BJ fibroblasts. The highest selectivity index values, on average, for the leaf extracts were obtained at the dose of $100 \mu \mathrm{g} / \mathrm{mL}$. Therefore, the dose of $100 \mu \mathrm{g} / \mathrm{mL}$ was selected for subsequent cell apoptosis studies and western blotting for ERK1/2 phosphorylation.

\section{Induction of Apoptosis by Carlina Leaf Extracts in Melanoma Cell Lines}

Cell apoptosis was analyzed using flow cytometry. The results are presented as a percentage change in the pan-caspase activity elicited by $100 \mu \mathrm{g} / \mathrm{mL}$ of the root or leaf extracts of C. acanthifolia subsp. utzka and C. acaulis subsp. caulescens normalized to the vehicle-treated controls (Figure 4). A significant increase in the caspase activity after incubation with the extracts from the leaves of C. acanthifolia subsp. utzka and C. acaulis subsp. Caulescens was observed in all three melanoma cell lines: UACC903, C32 and UACC-647 (Figures 4A-C, plain bars). This effect was not detected in melanoma cells treated with the root extracts (Figures 4A-C, striped bars). There was also no change in the caspase activity in control BJ fibroblast for the extracts from both the leaves and roots (Figure 4D).

\section{Inhibition of ERK Phosphorylation by Carlina Leaf Extracts}

To study the effects of Carlina extracts on phosphorylation of ERK1/2, UACC-903, C32, and UACC-647 melanoma cells as well as BJ normal fibroblasts were treated with $100 \mu \mathrm{g} / \mathrm{mL}$ of leaf and root extracts from C. acanthifolia subsp. utzka and C. acaulis subsp. caulescens. In UACC-903 cells, the treatment with leaf extracts from both $C$. acanthifolia subsp. utzka and C. acaulis subsp. caulescens led to significant inhibition of ERK phosphorylation (Figure 5A, compare lanes 1 vs. 2 and 1 vs. 4). However, no changes in the phospho-ERK levels were observed in UACC-903 cells treated with the root extracts from the same Carlina species (Figure 5A, compare lanes 1 vs. 3 and 1 vs. 5).

In the C32 melanoma cell line, asignificant drop in ERK1/2 phosphorylation was observed only for cells incubated with the leaf extract from $C$. acaulis subsp. caulescens, but not from C. acanthifolia subsp. utzka. In addition, treatment of the cells with the root extracts from both Carlina species described in this study caused no significant changes in the phosphoERK1/2 levels (Figure 5B). It should be noted that there were

TABLE 2 | The mean content of main constituents of extract $\left(\mu \mathrm{g} \cdot \mathrm{mL}^{-1} \mathrm{CE}\right)$.

\begin{tabular}{|c|c|c|c|c|c|}
\hline \multirow[b]{2}{*}{ Compounds } & \multirow[b]{2}{*}{ Mass data DIP-APCI ionization mode $[\mathrm{M}+\mathrm{H}]^{+}$} & \multicolumn{2}{|c|}{ C. acanthifolia subsp. utzka } & \multicolumn{2}{|c|}{ Carlina acaulis subsp. caulescens } \\
\hline & & Root extract & Leaf extract & Root extract & Leaf extract \\
\hline Ursolic acid & 457.3679 & - & $234.75 \pm 2.4$ & - & $553.28 \pm 5.2$ \\
\hline Oleanolic acid & 457.3661 & - & $225.77 \pm 2.3$ & - & $379.58 \pm 3.7$ \\
\hline Betulinic acid & 457.3671 & - & $45.06 \pm 0.41$ & - & $13.87 \pm 0.14$ \\
\hline Lupeol & 427.3942 & - & $3.44 \pm 0.04$ & - & $4.21 \pm 0.05$ \\
\hline Lupeol acetate & 469.4036 & $14.97 \pm 0.21$ & - & - & - \\
\hline$\beta$-amyrin & 427.3865 & - & $8.68 \pm 0.09$ & - & $3.03 \pm 0.04$ \\
\hline$\beta$-amyrin acetate & 469.4037 & $25.91 \pm 0.27$ & $4.73 \pm 0.05$ & $<\mathrm{LOQ}$ & - \\
\hline Chlorogenic acid & 355.1018 & $198.27 \pm 2.2$ & $244.58 \pm 2.3$ & $218.10 \pm 2.1$ & $184.69 \pm 1.97$ \\
\hline Protocatechuic acid & 155.0362 & - & $131.24 \pm 1.2$ & - & $98.24 \pm 1.19$ \\
\hline
\end{tabular}



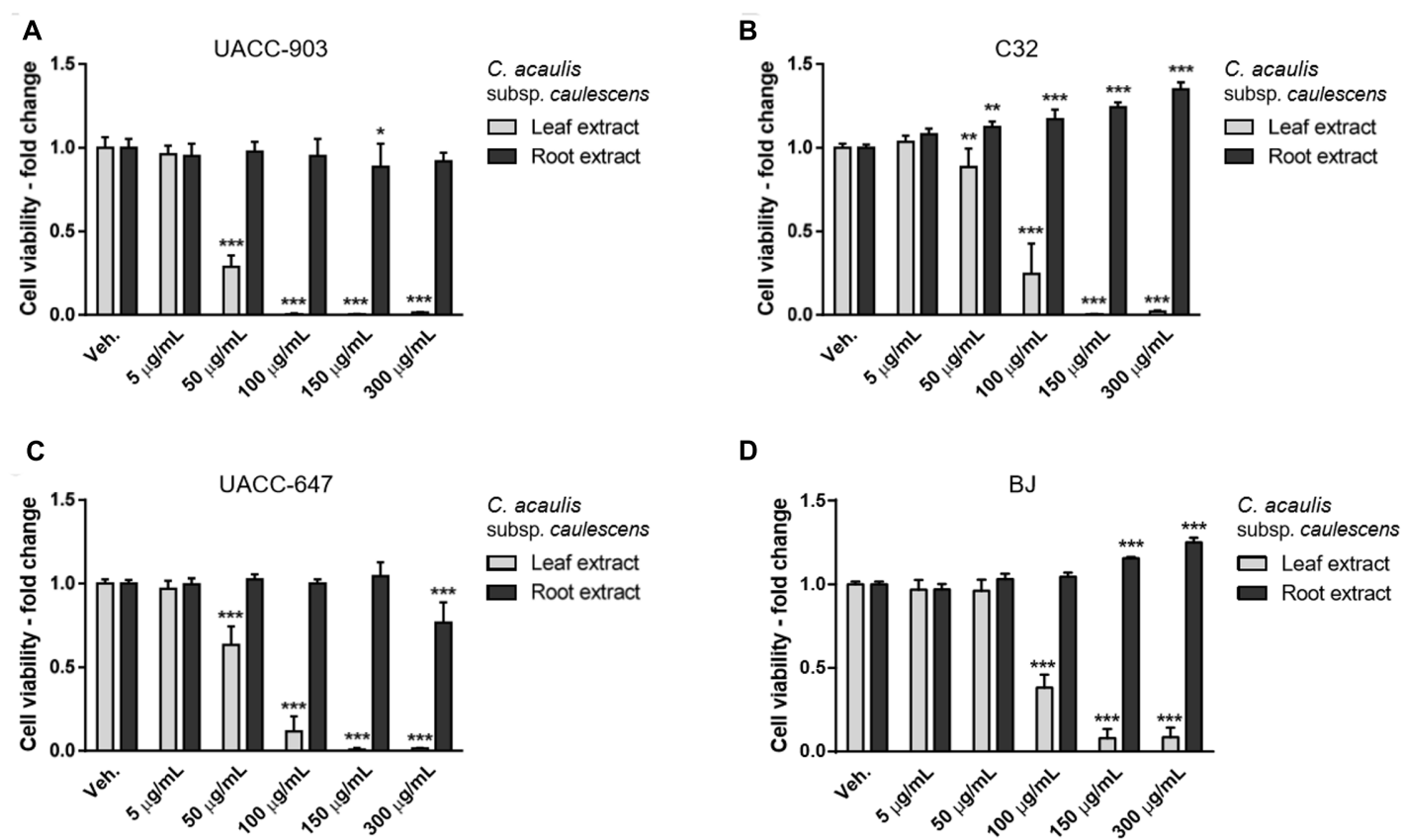

FIGURE 1 | Cytotoxicity of Carlina acaulis subsp. caulescens extracts from leaves and roots on the viability of human melanoma cells and normal human fibroblasts. UACC-903 (A), C32 (B), UACC-647 (C), and BJ (D) cells were plated in 96-well plates and treated for $24 \mathrm{~h}$ with vehicle (EtOH:DMSO, 1.1:0.4, v:v) or with 5, 50, 100,150 , and $300 \mu \mathrm{g} / \mathrm{mL}$ of $C$. acaulis subsp. caulescens leaf extracts. The viability of vehicle-treated cells was set at 1.0. Data points represent the average viability $\pm \mathrm{SD}$ of three independent experiments.
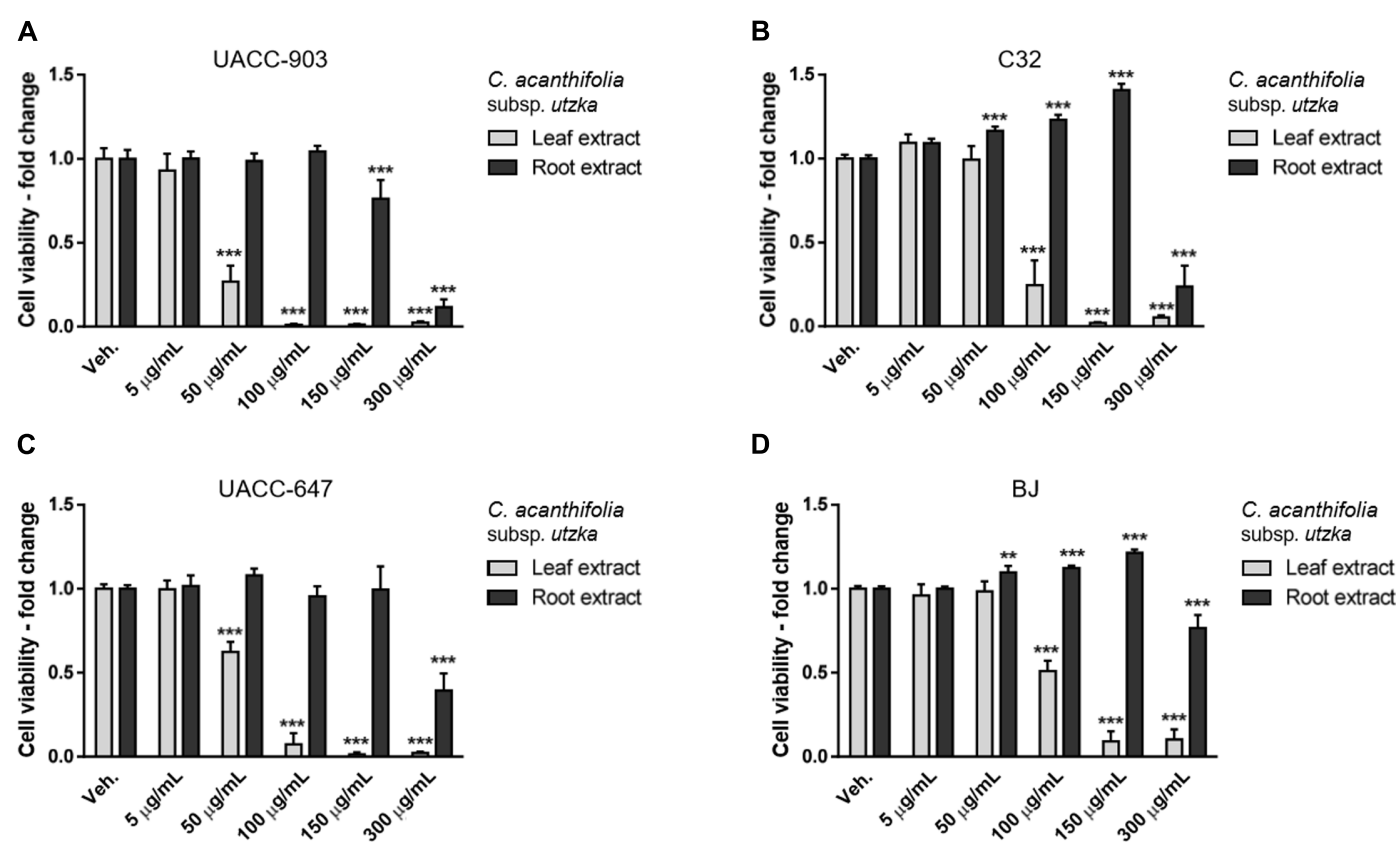

D

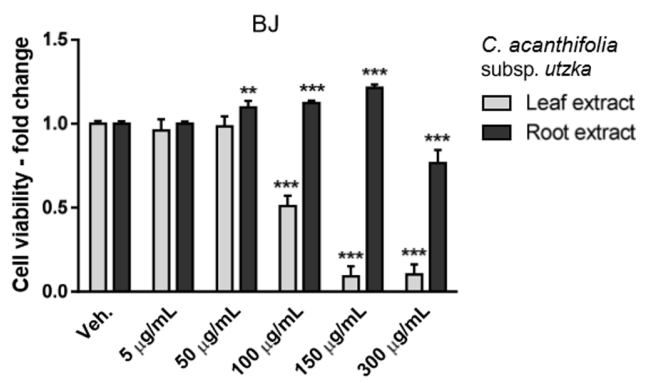

FIGURE 2 | Cytotoxicity of $C$. acanthifolia subsp. utzka extracts from leaves and roots on the viability of human melanoma cells and normal human fibroblasts. UACC-903 (A), C32 (B), UACC-647 (C), and BJ (D) cells were plated in 96-well plates and treated for $24 \mathrm{~h}$ with vehicle (EtOH:DMSO, 1.1:0.4, v:v) or with 5, 50, 100, 150, and $300 \mu \mathrm{g} / \mathrm{mL}$ C. acanthifolia subsp. utzka leaf extracts. The viability of vehicle-treated cells was set at 1.0. Data points represent the average viability $\pm S D$ of three independent experiments. 
TABLE 3 | $I C_{50}$ values for leaf extracts.

\begin{tabular}{|c|c|c|}
\hline \multirow[b]{2}{*}{ Cell line } & \multicolumn{2}{|c|}{$\mathrm{IC}_{50} \mu \mathrm{g} / \mathrm{mL}$} \\
\hline & $\begin{array}{c}\text { C. acaulis subsp. caulescens } \\
\text { leaf extract }\end{array}$ & $\begin{array}{c}\text { C. acanthifolia subsp. utzka } \\
\text { leaf extract }\end{array}$ \\
\hline UACC-903 & 43.2 & 40.1 \\
\hline UACC-647 & 57.9 & 56.1 \\
\hline C32 & 76.7 & 86.7 \\
\hline BJ & 89.5 & 99.6 \\
\hline
\end{tabular}

no significant changes in the level of ERK1/2 phosphorylation in UACC-647 cells after incubation with extracts obtained from Carlina leaves; however, phospho-ERK was significantly lowered after the treatment with the extract from the roots of C. acanthifolia subsp. utzka (Figure 5C).

The BJ fibroblasts were refractory to the treatments with extracts from both C. acanthifolia subsp. utzka and C. acaulis subsp. caulescens; no alterations in the phospho-ERK1/2 levels were observed in these cells (Figure 5D). The abundance of total ERK1/2 proteins was unaltered by the treatments in all tested cell lines.

\section{DISCUSSION}

Due to the lack of accurate data on preparation of traditional anticancer drugs from Carlina plants, methanol was used as a non-selective extractant. Therefore, it can be assumed that

A

\begin{tabular}{|c|c|c|c|c|}
\hline \multicolumn{2}{|c|}{ Cell line } & C32 & UACC-647 & UACC-903 \\
\hline \multirow{2}{*}{ Dose $[\mu \mathrm{g} / \mathrm{mL}]$} & & & \\
\hline \multirow{2}{*}{300} & Leaf extract & 4.77 & 6.62 & 6.60 \\
\cline { 2 - 5 } & Roots extract & 0.93 & 1.69 & 1.92 \\
\hline \multirow{2}{*}{$\mathbf{1 5 0}$} & Leaf extract & 17.67 & 10.23 & 18.29 \\
\cline { 2 - 6 } & Roots extract & 0.94 & 1.13 & 1.35 \\
\hline \multirow{2}{*}{100} & Leaf extract & 1.84 & 3.13 & 82.62 \\
\cline { 2 - 6 } & Roots extract & 0.89 & 1.04 & 1.10 \\
\hline \multirow{2}{*}{50} & Leaf extract & 1.10 & 1.52 & 3.34 \\
\cline { 2 - 6 } & Roots extract & 0.93 & 1.01 & 1.05 \\
\hline \multirow{2}{*}{5} & Leaf extract & 0.94 & 1.00 & 1.01 \\
\cline { 2 - 6 } & Roots extract & 0.90 & 0.98 & 1.04 \\
\hline
\end{tabular}

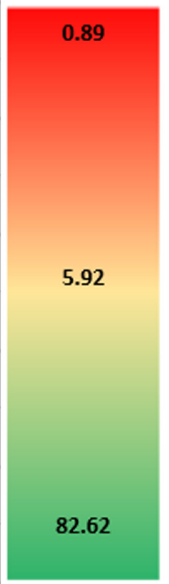

B

\begin{tabular}{|c|c|c|c|c|}
\hline \multicolumn{2}{|c|}{ Cell line } & C32 & UACC-647 & UACC-903 \\
\hline \multirow{2}{*}{ Dose $[\mu \mathrm{g} / \mathrm{mL}]$} & & & \\
\hline \multirow{2}{*}{$\mathbf{1} 300$} & Leaf extract & 1.95 & 4.57 & 4.40 \\
\cline { 2 - 6 } & Roots extract & 2.69 & 2.14 & 6.59 \\
\hline \multirow{2}{*}{100} & Leaf extract & 4.79 & 6.76 & 7.45 \\
\cline { 2 - 6 } & Roots extract & 0.85 & 1.27 & 1.65 \\
\cline { 2 - 6 } & Leaf extract & 2.31 & 6.97 & 44.77 \\
\hline \multirow{2}{*}{50} & Roots extract & 0.91 & 1.18 & 1.31 \\
\cline { 2 - 6 } & Leaf extract & 0.99 & 1.58 & 3.68 \\
\hline \multirow{2}{*}{5} & Roots extract & 0.94 & 1.02 & 1.11 \\
\cline { 2 - 6 } & Leaf extract & 0.87 & 0.96 & 1.03 \\
\hline
\end{tabular}

FIGURE 3 | Selectivity index of Carlina extracts towards melanoma cells versus normal human fibroblasts. The selectivity index was calculated by dividing the average viability of BJ cell line by the viability of the melanoma cell line of interest in respective C. acaulis subsp. caulescens (A) and C. acanthifolia subsp. utzka (B) extracts. The higher the value, the more selective towards a given melanoma cell line the extract is. Values of 1 or less indicate no selectivity towards melanoma cells. 
A
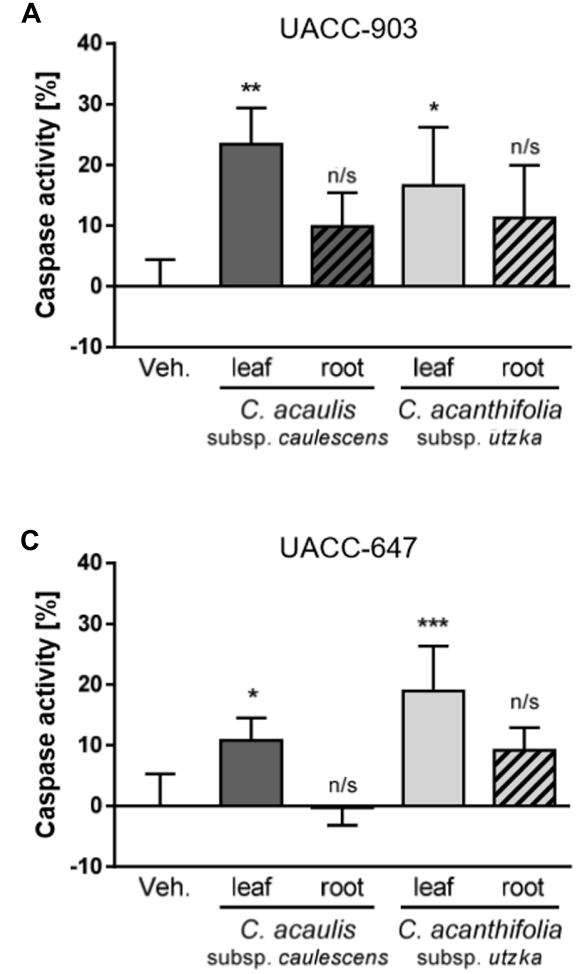

B

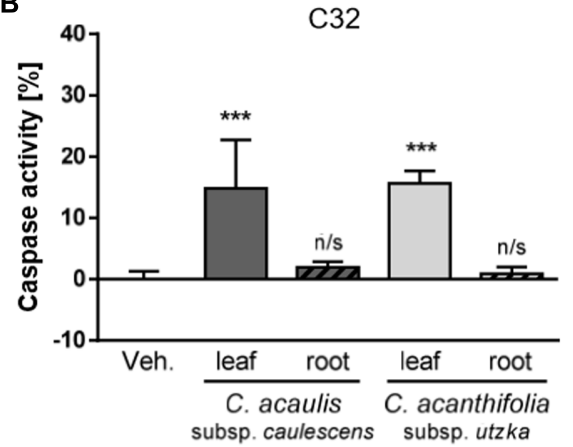

D

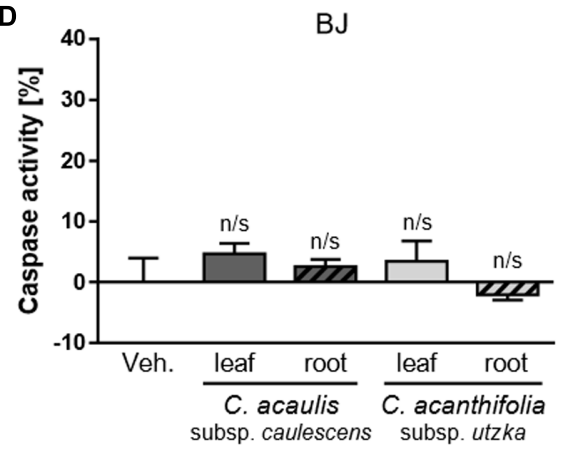

FIGURE 4 | Caspase activation in response to $C$. acaulis subsp. caulescens and C. acanthifolia subsp. utzka leaf and root extracts in human melanoma cell and in normal human fibroblasts. Caspase activity in UACC-903 (A), C32 (B), UACC-647 (C), and BJ (D) cells was measured in response to C. acaulis subsp. caulescens and C. acanthifolia subsp. utzka extracts from leaves and roots $24 \mathrm{~h}$ upon the treatment. The results obtained are plotted as a percentage change in caspase activity normalized to vehicle controls. Data points represent the average value \pm SD from three independent experiments.

the extracts obtained contain similar phytochemicals as folk medicinal preparations.

In this study, we demonstrated the cytotoxic and proapoptotic properties of extracts from the leaves of $C$. acaulis subsp. caulescens and C. acanthifolia subsp. utzka against human malignant melanoma cells. Moreover, the leaf extracts exhibited a lower level of toxicity against normal BJ fibroblasts in comparison with melanoma cells. The antiproliferative properties of the leaf extracts may be partially explained by the inhibition of ERK1/2 phosphorylation observed in the UACC-903 and C32 melanoma cells. RAF/MEK/ERK signaling pathway controls fundamental cellular processes such as growth, proliferation, differentiation, and migration (Dhillon et al., 2007). This pathway is central to progression of cutaneous melanomas, as it has been reported to be overactivated in up to $80 \%$ of all melanoma cases (McCubrey et al., 2007; Wang and Qi, 2013). UACC-903 (Wnorowski et al., 2015), C32 (Kang et al., 2013) and UACC-647 (Wnorowski et al., 2015) cell lines express high levels of phosphoactive ERK1/2 due to the activatory V600E substitution in upstream BRAF kinase (Alfano et al., 2008; Byron et al., 2012), a mutation common in melanomas (Moses et al., 2003). Multiple strategies have been developed to inhibit this pathway, including the use of specific inhibitors of RAF, MEK, and ERK kinases, however with varying effectiveness (Holderfield et al., 2014; Dhillon, 2016; Jha et al.,
2016). Since high levels of ursolic acid, a known inhibitor of ERK phosphorylation (Wang et al., 2013), were detected in the leaf extracts of C. acanthifolia subsp. utzka and C. acaulis subsp. caulescens (Table 1), the capabilities of the extracts to downmodulate phospho-ERK levels were assessed. However, there was no reduction in the p-ERK1/2 levels in the UACC-647 cell line treated with the same leaf extracts. Thus, other constituents affecting the antiproliferative actions of the leaf extracts or cell type-specific responses to such treatment were observed. The absence of significant changes in the level of phosphorylation of p-ERK1/2 in normal BJ fibroblasts correlates with relatively low activity of caspases.

The extracts were further investigated with the HPLC method. The analysis showed the presence of a rich triterpene fraction in the extracts from the leaves of $C$. acaulis subsp. caulescens and C. acanthifolia subsp. utzka. These extracts also contained significant amounts of chlorogenic and protocatechuic acids. The presence of phenolic acids and triterpenes, especially ursolic and oleanolic acids, may explain some of the antitumorigenic properties of the leaf extracts described in this study, as well as rationalize the application of Carlina species in traditional anticancer treatments. There are numerous reports on antiproliferative and proapoptotic properties of ursolic and oleanolic acids (Yan et al., 2010; Yang et al., 2012; Woźniak 


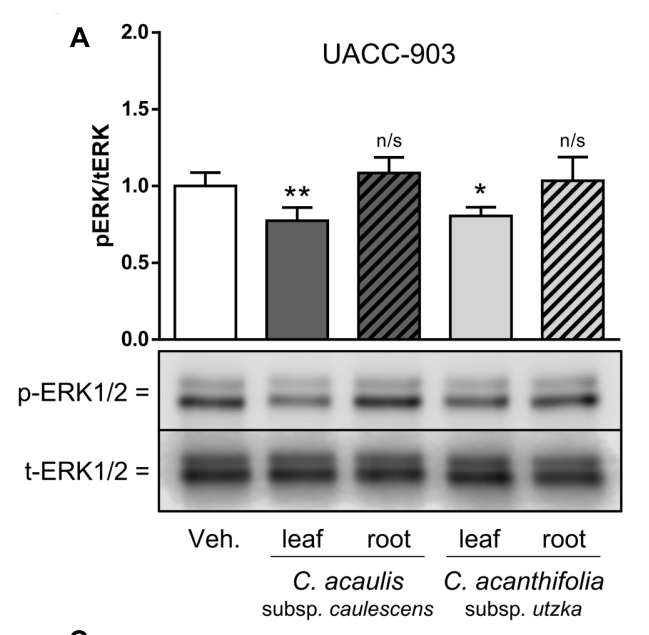

C

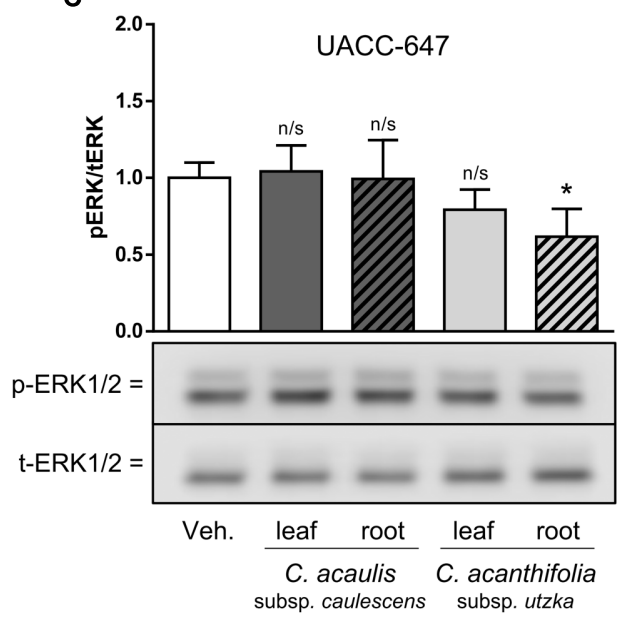



D
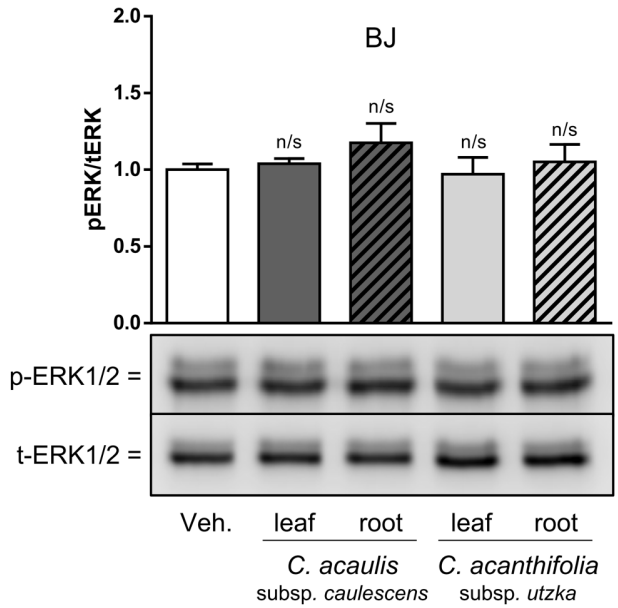

FIGURE 5 | Modulation of ERK1/2 phosphorylation in melanoma cells and in normal keratinocytes in response to C. acaulis subsp. caulescens and C. acanthifolia subsp. utzka extracts from leaves and roots. UACC-903 (A), C32 (B), UACC-647 (C), and BJ (D) were serum-starved for 3 h. Subsequently, the cells were treated with $100 \mu \mathrm{g} / \mathrm{mL}$ of leaf and root extracts from C. acaulis subsp. caulescens and C. acanthifolia subsp. utzka or vehicle for 30 min. The cells were lysed and immunoblotted for total and phosphorylated forms of ERK1/2. The immunoreactive bands obtained were quantified by means of volume densitometry. Bottom panels depict representative blots. Values on the graphs (top panels) represent means \pm SD from three independent experiments. Asterisk symbols depict differences in phospho-ERK1/2 in cells treated with the plant extracts versus vehicle-treated controls. ${ }^{* * *} P<0.001$; ${ }^{* *} P<0.01 ;{ }^{*} P<0.05 ; \mathrm{n} / \mathrm{s}$, not significant.

et al., 2015). In the study on the human melanoma M4Beu cell line, it was demonstrated that ursolic acid exerted a significant antiproliferative effect associated with caspase-3 activation (Harmand et al., 2005; Manu and Kuttan, 2008). It was shown that ursolic acid induced apoptosis of melanoma MM200, Mel-RM, Me4405, and A375 cell lines (Mahmoud et al., 2015). Moreover, it exhibited potential for protecting normal cells and sensitizing skin melanoma cells to UV irradiation (Lee et al., 2014). Apoptotic death of human malignant melanoma cells was also observed after incubation with oleanolic acid (A375 cells) (Cijo George et al., 2014) and betulinic acid (UISOMEL-1 cells) (Tan et al., 2003). There are also reports on the cytotoxic activity of amyrin and lupeol against different human melanoma cells (Saleem et al., 2008; Chaabane et al., 2013). Chlorogenic acid has been shown to inhibit proliferation and act cytotoxically to melanoma cell line B16 (Lee et al., 2014).
However, the cytotoxicity of the tested extracts against the UACC-903, UACC-647, and C32 lines is probably not associated with the presence of chlorogenic acid because the extract from roots that contained a high amount of this compound exhibited low or no cytotoxicity and did not induce apoptosis of the investigated cell lines. Although there are no reports on the activity of protocatechuic acid against human melanoma malignant cells, it has been demonstrated that this compound has cytotoxic activity and induces apoptosis in human malignant cells of different origin (Babich et al., 2002; Yin et al., 2009).

Quantified triterpenes and phenolic acids were dominant compounds in the tested extracts. A large number of reports on cytotoxicity and induction of apoptosis human melanoma malignant cells by these compounds suggest that they are largely responsible for the activity against UACC-903, UACC-647, and C32 lines. However, it should be noted that the activity of 
investigated extracts may be caused by a synergistic action of the constituents of the extracts.

The activity of the extracts on other types of tumor cell lines, e.g., breast cancer (DLD1) and colorectal adenocarcinoma cells (MDA MB-231) was also investigated; however, the cytotoxicity was significantly lower. Data for the DLD1 and MDA MB-231 lines have been included in the Supplementary material (Supplementary Figures S5, S6).

\section{CONCLUSION}

Our research demonstrated that extracts from the leaves of C. acaulis subsp. caulescens and C. acanthifolia subsp. utzka were cytotoxic against UACC-903, C32, and UACC-647 human melanoma cell lines and induced apoptosis of the cells. The triterpene fraction present in the tested extracts was probably responsible for the observed anti-tumor activity. These results rationalize the traditional medicinal application of the leaves from the plants of Carlina genus to treat skin cancer. This work presents the first report on the antiproliferative activity of Carlina plants in vitro.

\section{REFERENCES}

Alfano, R. W., Leppla, S. H., Liu, S., Bugge, T. H., Herlyn, M., Smalley, K. S., et al. (2008). Cytotoxicity of the matrix metalloproteinase-activated anthrax lethal toxin is dependent on gelatinase expression and B-RAF status in human melanoma cells. Mol. Cancer Ther. 5, 1218-1226. doi: 10.1158/1535-7163. MCT-08-0024

Babich, H., Sedletcaia, A., and Konigsberg, B. (2002). In vitro cytotoxicity of protocatechuic acid to cultured human cells from oral tissue: involvement in oxidative stress. Pharmacol. Toxicol. 91, 245-253. doi: 10.1034/j.1600-0773. 2002.910505.x

Barnwell, J. W., Ockenhouse, C. F., and Knowles, D. M. (1985). Monoclonal antibody OKM5 inhibits the in vitro binding of Plasmodium falciparuminfected erythrocytes to monocytes, endothelial, and C32 melanoma cells. J. Immunol. 135, 3494-3497.

Bittner, M., Meltzer, P., Chen, Y., Jiang, Y., Seftor, E., Hendrix, M., et al. (2000). Molecular classification of cutaneous malignant melanoma by gene expression profiling. Nature 406, 536-540. doi: 10.1038/35020115

Bonet, M. A., Parada, M., Selga, A., and Valle‘s, J. (1999). Studies on pharmaceutical ethnobotany in the regions of L'Alt Emporda' and Les Guilleries (Catalonia, Iberian Peninsula). J. Ethnopharmacol. 68, 145-168. doi: 10.1016/S03788741(99)00083-5

Byron, S. A., Loch, D. C., Wellens, C. L., Wortmann, A., Wu, J., Wang, J., et al. (2012). Sensitivity to the MEK inhibitor E6201 in melanoma cells is associated with mutant BRAF and wildtype PTEN status. Mol. Cancer 11:75. doi: 10.1186/ 1476-4598-11-75

Chaabane, F., Pinon, A., Simon, A., Ghedira, K., and Chekir-Ghedira, L. (2013). Phytochemical potential of Daphne gnidum in inhibiting growth of melanoma cells and enhancing melanogenesis of B16-F0 melanoma. Cell Biochem. Funct. 31, 460-467. doi: 10.1002/cbf.2919

Cijo George, V., Naveen Kumar, D. R., Suresh, P. K., and Ashok Kumar, R. (2014). Oleanolic acid inhibits cell growth and induces apoptosis in A375 melanoma cells. Biomed. Prev. Nutr. 4, 95-99. doi: 10.1016/S2095-4964(14) 60015-7

Dénes, A., Papp, N., Babai, D., Czúcz, B., and Molnár, Z. (2012). Wild plants used for food by hungarian ethnic groups living in the carpathian basin. Acta Soc. Bot. Pol. 4, 381-396. doi: 10.5586/asbp.2012.040

Dhillon, A. S., Hagan, S., Rath, O., and Kolch, W. (2007). MAP kinase signaling pathways in cancer. Oncogene 26, 3279-3290. doi: 10.1038/sj.onc.1210421

\section{AUTHOR CONTRIBUTIONS}

MS idea for experiment; MS, KW, KW-K, PK, and AW designed research; MS, KW, KW-K, MW-K, RK, ML, IS, and JS conducted research and analyzed data; MS, KW, KW-K, and AW wrote the paper. All authors read and approved the final manuscript.

\section{ACKNOWLEDGMENTS}

This work was partially supported by the Botanical Garden of Maria Curie-Sklodowska in Lublin and by internal founding form the Medical University of Lublin. We thank Ph.D. Grażyna Szymczak and Ph.D. Mykhaylo Chernetskyy for the access to the Carlina plants.

\section{SUPPLEMENTARY MATERIAL}

The Supplementary Material for this article can be found online at: http://journal.frontiersin.org/article/10.3389/fphar. 2017.00371/full\#supplementary-material

Dhillon, S. (2016). Dabrafenib plus trametinib: a review in advanced melanoma with a BRAF (V600) mutation. Target. Oncol. 3, 417-428. doi: 10.1007/s11523016-0443-8

Đorđević, S., Petrović, S., Dobrić, S., Milenković, M., Vučićević, D., Žižić, S., et al. (2007). Antimicrobial, anti-inflammatory, anti-ulcer and antioxidant activities of Carlina aanthifolia root essential oil. J. Ethnopharmacol. 109, 458-463. doi: 10.1016/j.jep.2006.08.021

Đorđević, S., Petrović, S., Ristić, M., and Djoković, D. (2005). Composition of Carlina acanthifolia root essential oil. Chem. Nat. Compd. 4, 410-412. doi: 10.1007/s10600-005-0163-2

Đorđević, S., Tadić, V., Petrović, S., Kukić-Marković, J., Dobrić, S., Milenković, M., et al. (2012). Bioactivity assays on Carlina acaulis and C. acanthifolia root and herb extracts. Dig. J. Nanomater. Bios. 3, 1213-1222.

Duke, J. A., Bogenschutz-Godwin, M. J., duCellier, J., and Duke, P.-A. (2002). Handbook of Medicinal Herbs. New York, NY: CRC Press. doi: 10.1201/ 9781420040463

Guarino, C., De Simone, L., and Santoro, S. (2008). Ethnobotanical study of the sannio area, campania, southern italy. Ethnobot. Res. App. 6, 255-317. doi: 10.1186/1746-4269-5-7

Guarrera, P. M. (2003). Food medicine and minor nourishment in the folk traditions of central Italy (Marche, Abruzzo and Latium). Fitoterapia 74, 515-544. doi: 10.1016/S0367-326X(03)00122-9

Harmand, P. O., Duval, R., Delage, C., and Simon, A. (2005). Ursolic acid induces apoptosis through mitochondrial intrinsic pathway and caspase- 3 activation in M4Beu melanoma cells. Int. J. Cancer 1, 1-11. doi: 10.1002/ijc.20588

Henneberg, M. (2002). "Recherche d'agents antineoplastics parmi les plantes de la flore ethnopharmacologique de la Lituanie," in Des Sources du Savoir Aux Médicaments du Future - From the Sources of Knowledge to the Medicines of the Future, 1st Edn, eds J. Fleurentin, J. M. Pelt, and G. Mazars (Paris: IRD Editions), 433-435.

Holderfield, M., Deuker, M. M., McCormick, F., and McMahon, M. (2014). Targeting RAF kinases for cancer therapy: BRAF-mutated melanoma and beyond. Nat. Rev. Cancer 14, 455-467. doi: 10.1038/nrc3760

Jaiswal, R., Deshpande, S., and Kuhnert, N. (2011). Profiling the chlorogenic acids of Rudbeckia hirta, Helianthus tuberosus, Carlina acaulis and Symphyotrichum novae-angliae leaves by LC-MSn. Phytochem. Anal. 22, 432-441. doi: 10.1002/ pca.1299

Jarić, S., Popović, Z., Mačukanović-Jocić, M., Djurdjević, L., Mijatović, M., Karadžić, B., et al. (2007). An ethnobotanical study on the usage of wild 
medicinal herbs from kopaonik mountain (Central Serbia). J. Ethnopharmacol. 111, 160-175. doi: 10.1016/j.jep.2006.11.007

Jha, S., Morris, E. J., Hruza, A., Mansueto, M. S., Schroeder, G. K., Arbanas, J., et al. (2016). Dissecting therapeutic resistance to ERK inhibition. Mol. Cancer Ther. 4, 548-559. doi: 10.1158/1535-7163.MCT-15-0172

Kang, K.-H., Ling, T.-Y., Liou, H.-H., Huang, Y.-K., Hour, M.-J., Liou, H.-C., et al. (2013). Enhancement role of host 12/15-lipoxygenase in melanoma progression. Eur. J. Cancer. 12, 2747-2759. doi: 10.1016/j.ejca.2013.03.030

Lee, Y. H., Wang, E., Kumar, N., and Glickman, R. D. (2014). Ursolic acid differentially modulates apoptosis in skin melanoma and retinal pigment epithelial cells exposed to UV-VIS broadband radiation. Apoptosis 19, 816-828. doi: 10.1007/s10495-013-0962-Z

Mahmoud, M., Rabe, S. Z. T., Balali-Mood, M., Karimi, G., Tabasi, N., and Riahi-Zanjani, B. (2015). Ursolic acid induced apoptotic cell death following activation of caspase in isolated human melanoma cells. Cell Biol. Int. 39, 230-236. doi: 10.1002/cbin.10376

Manu, K. A., and Kuttan, G. (2008). Ursolic acid induces apoptosis by activating p53 and caspase- 3 gene expressions and suppressing NF- $\kappa$ B mediated activation of bcl-2 in B16F-10 melanoma cells. Int. Immunopharmacol. 7, 974-981. doi: 10.1016/j.intimp.2008.02.013

McCubrey, J. A., Steelman, L. S., Chappell, W. H., Abrams, S. L., Wong, E. W. T., Chang, F., et al. (2007). Roles of the Raf/MEK/ERK pathway in cel growth, malignant transformation and drug resistance. Biochim. Biophys. Acta 1773, 1263-1284. doi: 10.1016/j.bbamcr.2006.10.001

Menale, B., Amato, G., Di Prisco, C., and Muoio, R. (2006). Traditional uses of plants in North-Western molise (Central Italy). Delpinoa 48, 29-36.

Menković, N., Šavikin, K., Tasić, S., Zdunić, G., Stešević, D., Milosavljević, S., et al. (2011). Ethnootanical study on traditional uses of wild medicinal plants Prokletije Mountains (Montenegro). J. Ethnopharmacol. 133, 97-107. doi: 10. 1016/j.jep.2010.09.008

Meusel, H., and Kästner, A. (1994). Lebensgeschichte der Gold - und Silberdisteln. Monographie der Mediterran - Mitteleuropaischen Compositen-Gattung Carlina. New York, NY: Springer-Verlag. doi: 10.1007/978-3-7091-3069-8

Miler, D. (2009). Prirodna Medicina. Belgrade: Metaphysica.

Morales, C. P., Holt, S. E., Ouellette, M., Kaur, K. J., Yan, Y., Wilson, K. S., et al. (1999). Absence of cancer-associated changes in human fibroblasts immortalized with telomerase. Nat. Genet. 21, 115-118. doi: 10.1038/5063

Moses, T. T., Hostetter, G., Wagner, U., Kakareka, J., Salem, G., Pohida, T., et al. (2003). High frequency of BRAF mutations in nevi. Nat. Genet. 33, 19-20. doi: $10.1038 /$ ng 1054

Orthaber, K., Pristovnik, M., Skok, K., Perić, B., and Maver, U. (2017). Skin cancer and its treatment: novel treatment approaches with emphasis on nanotechnology. J. Nanomater. 2017, 1-20. doi: 10.1016/j.jconrel.2016.10.023

Paul, R. K., Wnorowski, A., Gonzalez-Mariscal, I., Nayak, S. K., Pajak, K., Moaddel, R., et al. (2014). (R,R')-4'-methoxy-1-naphthylfenoterol targets GPR55-mediated ligand internalization and impairs cancer cell motility. Biochem. Pharmacol. 4, 547-561. doi: 10.1016/j.bcp.2013.11.020

Pieroni, A., Nedelcheva, A., Hajdari, A., Mustafa, B., Scaltriti, B., Cianfaglione, K., et al. (2014). Local knowledge on plants and domestic remedies in the mountain villages of peshkopia (Eastern Albania). J. Mt. Sci. 1, 180-194. doi: 10.1007/ s11629-013-2651-3

Raynaud, J., and Rasolojaona, L. (1979). Flavonoides des feuilles de Carlina acaulis. Planta Med. 10, 168-171. doi: 10.1055/s-0028-1097319

Redžić, S. S. (2007). The ecological aspect of ethnobotany and ethnopharmacology of population in Bosnia and Herzegovina. Coll. Antropol. 3, 869-890.

Rexhepi, B., Mustafa, B., Hajdari, A., Rushidi-Rexhepi, J., Quave, C. L., and Pieroni, A. (2013). Traditional medicinal plant knowledge among albanians, macedonians and gorani in the sharr mountains (republic of macedonia). Genet. Resour. Crop. Evol. 60, 2055-2080. doi: 10.1007/s10722-013-9974-3

Saleem, M., Maddodi, N., Abu Zaid, M., Khan, N., bin Hafeez, B., Asim, M., et al. (2008). Lupeol inhibits growth of highly aggressive human metastatic melanoma cells in vitro and in vivo by including apoptosis. Clin. Cancer Res. 14, 2119-2127. doi: 10.1158/1078-0432.CCR-07-4413

Šarić-Kundalić, B., Dobeš, C. H., Klatte-Asselmeyer, V., and Saukel, J. (2010). Ethnobotanical study on medicinal use of wild and cultivated plants in middle, south and west Bosnia and Herzegovina. J. Ethnopharmacol. 131, 33-55. doi: 10.1016/j.jep.2010.05.061

Schindelin, J., Arganda-Carreras, I., Frise, E., Kaynig, V., Longair, M., Pietzsch, T., et al. (2012). Fiji: an open-source platform for biological-image analysis. Nat. Methods 7, 676-682. doi: 10.1038/nmeth.2019

Stojanović-Radić, Z., Ėomić, L., Radulović, N., Blagojević, P., Mihajilov-Krstev, T., and Rajković, J. (2012). Commercial Carlinae radix herbal drug: botanical identity, chemical composition and antimicrobial properties. Pharm. Biol. 8, 933-940. doi: 10.3109/13880209.2011.649214

Strzemski, M., Typek, J., Rydzik, E., Furtak, M., Chernetskyy, M., and Szymczak, G. (2014a). Carlina onopordifolia (Carlina onopordifolia Basser) a plant of xerothermic grassland in Poland and Ukraine. Acta Carpathica 16, 61-65.

Strzemski, M., Wójciak-Kosior, M., Sowa, I., Rutkowska, E., Szwerc, W., Kocjan, R., et al. (2016). Carlina species as a new source of bioactive pentacyclic triterpenes. Ind. Crop. Prod. 94, 498-504. doi: 10.1016/j.indcrop.2016.09.025

Strzemski, M., Zapała, K., Furtak, M., Rydzik, E., and Typek, J. (2014b). The medical uses of carline thistle (Carlina acaulis L.) in polish botanical and pharmaceutical literature. Acta Carpathica 21, 43-48.

Szafer, W., Kulczyñski, S., and Pawłowski, B. (1976). Polish Plants. Warsaw: State Scientific Publishing.

Tan, Y., Yu, R., and Pezzuto, J. M. (2003). Betulinic acid-induced programmed cell death in human melanoma cells involves mitogen-activated protein kinase activation. Clin. Cancer Rec. 9, 2866-2875.

Trent, J. M., Stanbridge, E. J., McBride, H. L., Meese, E. U., Casey, G., Araujo, D. E., et al. (1990). Tumorigenicity in human melanoma cell lines controlled by introduction of human chromosome 6. Science 247, 568-571. doi: 10.1126/ science. 2300817

Tutin, T. G., Heywood, V. H., Burges, N. A., Moore, D. M., Valentine, D. H., Walters, S. M., et al. (1976). Flora Europea. Cambridge: Cambridge University Press.

Wang, A.-X., and Qi, X.-Y. (2013). Targeting RAS/RAF/MEK/ERK signaling in metastatic melanoma. IUBMB Life 9, 748-758. doi: 10.1002/iub.1193

Wang, J., Liu, L., Qiu, H., Zhang, X., Guo, W., Chen, W., et al. (2013). Ursolic acid simultaneously targets multiple signaling pathways to suppress proliferation and induce apoptosis in colon cancer cells. PLOS ONE 5:e63872. doi: 10.1371/ journal.pone.0063872

Wnorowski, A., Sadowska, M., Paul, R. K., Singh, N. S., Boguszewska-Czubara, A., Jimenez, L., et al. (2015). Activation of $\beta 2$-adrenergic receptor by (R,R')-4'methoxy-1-naphthylfenoterol inhibits proliferation and motility of melanoma cells. Cell. Signal. 27, 997-1007. doi: 10.1016/j.cellsig.2015.02.012

Woźniak, Ł., Skạpska, S., and Marszałek, K. (2015). Ursolic acid-a pentacyclic triterpenoid with a wide spectrum of pharmacological activities. Molecules 20, 20614-20641. doi: 10.3390/molecules201119721

Yan, S. L., Huang, C. Y., Wu, S. T., and Yin, M. C. (2010). Oleanolic acid and ursolic acid induce apoptosis in four human liver cancer cell lines. Toxicol. In Vitro 3, 842-848. doi: 10.1016/j.tiv.2009.12.008

Yang, J. S., Liu, C. W., Ma, Y. S., Weng, S. W., Tang, N. Y., Wu, S. H., et al. (2012). Chlorogenic acid induces apoptotic cell death in U937 leukemia cells through caspase- and mitochondria-dependent pathways. In Vivo 6, 971-978.

Yin, M. C., Lin, C. C., Wu, H. C., Tsao, S. M., and Hsu, C. K. (2009). Apoptotic effects of protocatechuic acid in human breast, lung, liver, cervix, and prostate cancer cells: potential mechanism of action. J. Agric. Food Chem. 57, 6468-6473. doi: $10.1021 /$ jf9004466

Conflict of Interest Statement: The authors declare that the research was conducted in the absence of any commercial or financial relationships that could be construed as a potential conflict of interest.

Copyright (c) 2017 Strzemski, Wojnicki, Sowa, Wojas-Krawczyk, Krawczyk, Kocjan, Such, Latalski, Wnorowski and Wójciak-Kosior. This is an open-access article distributed under the terms of the Creative Commons Attribution License (CC BY). The use, distribution or reproduction in other forums is permitted, provided the original author(s) or licensor are credited and that the original publication in this journal is cited, in accordance with accepted academic practice. No use, distribution or reproduction is permitted which does not comply with these terms. 